\title{
Matched Related Donor
}

National Cancer Institute

\section{Source}

National Cancer Institute. Matched Related Donor. NCI Thesaurus. Code C131675.

A donor who is related to the transplant recipient, and who is a human leukocyte antigen (HLA) tissue type match. 